\title{
Türkçe Ezan Uygulamasının Toplumsal Hafızada Yol Açtığı Travmalar Üzerine
}

Rifat Atay

Öz: Bu makalede, Cumhuriyet tarihinin ilk çeyreğinde milli din anlayışı çevresinde uygulamaya konan ve yaklaşık on sekiz yıl devam eden Türkçe ezan denemesinin toplumsal hafızada yarattığı travmaların bir değerlendirmesi yapılmaktadır. Bu çalışmada bir dini gösterge olarak ezanın önemini vurgulayan kısa girișten sonra ezanın sembolik anlamı üzerinde durulmuş, devamında ise anadilde ibadet tartışmaları ve Türkçe ezan uygulamasının kısa bir tarihçesi verilmiştir. Son olarak yazılı kaynaklar ve tanıklara dayanarak toplumsal hafızada konuya dair yansıyan birikimler sunulmuştur. Müslümanlar için evrensel bir çağrı niteliği olan ezanın millileştirilmesi çabaları, toplumdan en sert direnişi görmüştür. Ezanı Arapça okuyanların hapis ve para cezasına çarptırılmalarına rağmen uygulamada başarıya ulaşılamamış ve yasak 1950 yılında kaldırılmıştır.

Anahtar Kelimeler: Türkçe Ezan, Toplumsal Hafıza, Travma, Din, Siyaset

\section{On the Traumas Caused by the Turkish Adhan Experiment in Social Memory}

Abstract: This article makes an evaluation of the traumas created by the Turkish Adhan experiment, which has been implemented pursuant to the national religious concept in the first quarter of the history of the Turkish republic and lasted for about eighteen years. After a brief introduction emphasizing the importance of the call for prayer as a religious phenomenon, the symbolic meaning of adhan was followed by the discussions of worshipping in mother tongue, and a brief history of the Turkish call to prayer has been presented. Subsequently, based on written sources and testimonies, the accumulation in the social conscience which is about the subject was presented. The efforts to nationalize the call to prayer, which is a universal call for all Muslims, has seen the toughest resistance from the society. Even though those who recited the Adhan in Arabic were sentenced to imprisonment and a fine, the experiment failed and was eventually abolished in 1950 .

Keywords: Turkish Adhan, Social Memory, Trauma, Religion, Politics

\footnotetext{
* Doç. Dr., Akdeniz Üniversitesi, illahiyat Fakültesi, Felsefe ve Din Bilimleri Bölümü, Antalya, rifatay@akdeniz.edu.tr
} 


\section{Giriş}

Herhangi bir dinin zahiri varlığının en bariz işaretlerinden biri onun ibadet vakitlerinin kamuya en açık, yaygın ve erişilebilir olarak duyurulmasıdır. İslam tarihinde ezanın öyküsü de bunun önemini teyit eder. Ezan başlamadan önce ateş, duman, boru üfleme gibi değerlendirilen tercihler hem diğer dinlere aidiyeti hem de yeterince estetik ve etkin olmamaları nedeniyle itibar görmemiştir. Diğer ihtimaller karşısında ezanın sesle yapılan bir davet aracı olarak öne çıkması şaşırtıcı olduğu kadar ilginçtir. Bir defa ilahi kaynaklı olması önemini vurgulamada çoğu tartışmaya karşı onu öne geçirmektedir. Buna ilaveten doğrudan insan kaynaklı estetik bir araç olması en önemli özelliğidir. Diğer dinlerde kullanılan araçlarla mukayese edildiğinde doğrudan insan kaynaklı olması ve estetik değeri ezanı açık ara öne çıkarmaktadır. Hristiyanların çanı, Mecusilerin ateşi, Yahudilerin borusu da insan eli ile ortaya çıkan şeylerdir. Ama ezandaki estetik yoğunluğun doğurabildiği bazı sonuçlar ezanın özgül etkisini teyit etmektedir. Nitekim, bundan dolayı, İslam'la müşerref olan çoğu mühtedinin dinle tanışması ve önce cami, sonra da kültüre girmesindeki ilk etkenlerden biri ve belki de en yaygını "ezan” tecrübesidir. (Kamiloğlu, 2010: 221-237; Gürsu, 1999: 178)

Diğer bir ifadeyle ezanın, sözün büyüsüne musikinin maharetini ekleyerek çok etkin iki vasıtalı bir ilan aracına dönüşmüş olduğu söylenebilir. Ezandaki bu söz ve musiki büyüsünden birine dokunulduğunda ise tarihsel anlamıla birlikte etkisini de yitireceğini tahmin etmek güç değildir. Nitekim Cumhuriyet tarihinde ezanın Türkçeleştirilmesi girişimi olumsuz sonuçlar doğurmuştur. Belki Türkçe ezanın estetik ve musiki boyutu düzeltilebilirdi ama sözün yerini alabilecek hiçbir tercüme yoktur. Bu durum, Türkçe ezan denemesinin başarısız olmasının nedenlerinden biridir.

Toplumsal travmanın izlerini tahkik etmeye geçmeden önce söz ve musikinin etkinliği konusundaki ${ }^{1}$ tespitlerden ikisini sunmak uygun olacaktır. İslam ve estetik konusunda yazan ve kendisi de bir şair olan çağdaş felsefeci Turan Koç, "kutsal sanat" telakki ettiği ezan konusunda şu tespitlerde bulunmaktadır:

"Bilindiği gibi tevhid ilanı ve namaza çağrı gibi dini işlevleri olan ezanın geleneksel okunuşu başlı başına estetik bir olaydır. Tekrar eden cümlelerin ilki, belli bir nağme ile genellikle kısa tutulurken; ikincisi, seçilen makama göre uzatılarak okunur. Bazı durumlarda iki müezzin bunu karşılıklı ya da münavebeli bir şekilde icra ederler. Sultan Ahmed Camii'nde olduğu gibi, böyle durumlarda ezan çok daha büyüleyici bir etkiye sahip olur. Burada ihsan, ezanın fonksiyonel yanına estetik bir

\footnotetext{
${ }^{1}$ Söz ve musikiye geçmeden önce, sözleri oluşturan harfler ve onların birbirleri ile ilişkisi gibi konularda da Müslüman bilginler önemli çalışmalar yapmışlardır. Söz gelimi, Arap Dili ve Belagatinin yanında Tecvit gibi ayrı bir ilim dalı gelişmiştir. Belki ezan denemesinin başarıya ulaşmamasının nedenlerinin bir kısmını da bu tür çalışmaların oluşturduğu köklü gelenekte aramak yerinde olacaktır. Bu konuda birkaç örnek için bkz.: (İnce, 2016: 117-146; İnce, 2015: 71-205; Ince, 2010: 165-180).
} 
boyut eklenmek suretiyle tezahür ettirilmiş, böylece çağrı daha bir güzelleştirilmiştir." (Koç, 2008: 174)

Koç'un içeriden bakışını neredeyse birebir teyit eden Oliver Leaman da İslam'da estetik düşünce üzerine yazdığı eserinde benzer şeyleri söyledikten sonra Şam’a yaptığı ziyaretindeki gözlem ve düşüncelerini şöylece dile getirir:

“Şam'daki Emevi Camii'ni son ziyaretim esnasında, her bir minarede ayrı bir müezzin vardı ve her biri ezanı çok ince bir farkla değişik tarzlarda okuyorlardı. Bu gerçekten olağanüstü bir etki yaratır. Ezanın amacının yalnızca insanları namaza çağırmak olduğu, bunu aşırı abartmanın bu denli sade ve basit bir şeyi estetik bir hadiseye dönüștürebileceği de ileri sürülebilir. Hatta daha da ileri gidilerek, ezan okumak için inşa edilen minarelerin, mikrofonların kullanılmaya başlanmasıyla birlikte gereksizleştiği de savunulabilir. Ancak minarelerin hala muhafaza edilmesi güzelliğinden ve bu güzelliğin, tıpkı ezanın müzikalitesinin güzelliği gibi kişiyi camiye gitmeye teşvik etmesinden kaynaklanır." (Leaman, 2012: 159)

Leaman'ın dikkat çektiği son nokta olan ezanın insanı camiye gitmeye teşvik etmesi meselesi, Türkçe ezan denemesindeki önemli yönlerden biridir. Türkçe ezan, çoğu kişinin hatırasında teşvik şöyle dursun itici hatta üzücü bir işlev üstlenmiştir.

Hem öğrenilmesi ve icrası hem de anlamı açısından dikkate alındığında ilk bakışta ezanın Arapça olması bir dezavantaj gibi görünmekle beraber özellikle tecrübi birikim ve estetik yaygınlık açısından hayati bir işlevsellik sağlamaktadır. On sekiz yıl ısrarla denenen Türkçe ezan uygulamasının başarılı olamamasının belki de en bariz sebeplerinden birisi Türkçe ezanın Müslüman toplumsal hafızadaki tecrübi birikimler ile uyuşmazlığıdır.

\section{Ezanın Sembolik Anlamı}

İslam mezheplerinin çoğunluğuna göre bir yerde ezan okunması o bölgenin Müslüman olduğunun temel belirtisidir. Çünkü ezan, Arapça haliyle İslam'ın bir şiarıdır ve ancak bu şekilde duyanlara bir anlam ifade etmektedir. Wittgenstein'in ifadesiyle söylersek anlam, kelimelerle işaretlenen şeylerden çok daha fazlasıdır. (Wittgenstein, 2007: 29-32, 127) ${ }^{2}$ Bu meyanda bir Müslüman'ın kendi anlam dünyasında ezandan umduğu, asla onu kendi dili ile anlamak değildir. Zira ezan, bir Müslüman için kendi lisanında ne manaya geldiğini hatırlatmayacak derecede karşılığı olduğu kelimelerden ve dilden bağımsız, anlamın ta kendisidir. Marshall McLuhan'ın, kitabına başlık olarak kullandığı 'The Medium is the Message,' yani 'araç, mesajın ta kendisidir' ifadeleriyle dile getirmeye çalıştığı da budur. (McLuhan

\footnotetext{
2 Örneğin, sözcüklerin işlevi bağlamında Wittgenstein, "Bir sözcüğün nasıll iş gördüğünü tahmin edemeyiz, kullanılışına bakmamız ve buradan öğrenmemiz gerekir,” der. (Wittgenstein, 2007: 127) Yine benzer şekilde, dil anlam ilişkisi vurguladığı, "Bir dil tasavvur etmek, bir yaşam biçimi tasavvur etmektir," tespitini de hatırlamak yararlı olacaktır. (Wittgenstein, 2007: 29). Daha fazla bilgi için bkz.: Wittgenstein, 1974: 19-20; Putnam, 1997: 215-220.
} 
ve Fiore, 1967) Bir yurt gezisi esnasında o an okunan ezanın ne anlama geldiğini soran Atatürk'e cami imamının verdiği cevap da işlevselliğe işaret etmektedir: "Müslümanları namaza çağrı." (Gez, 1996: 159) Türkçe ezan uygulamasının anlamsızlığını ortaya koyduğu bir yazısında ise Ömer Rıza Doğrul bu durumu şöyle betimlemektedir:

“Biz ezan'ın Türkçe okunması aleyhinde değiliz. Fakat bunun lüzumsuz bir külfet, faydasız bir teşebbüs olduğuna inanıyoruz. Çünkü Türk'ün bildiği ve benimsediği Ezan-ı Muhammedî Arapça değil, fakat İslamcadır ve İslamca olduğu için hem Arapça'dır, hem Türkçe'dir, hem Acemce'dir, hatta hem Hindce'dir, hem Çince'dir. O, bir müșterek dildir ki bu camiaya bağlı olanların hepsi anlarlar, kelimelerini belki akılları kavrayamaz, fakat ruhları kelimelerin içyüzünü kavrar. Allahu Ekber Arapça değil, İslamcadır ve İslamca olduğu için Türkçedir." (Cündioğlu, 2005: 139)

Dil konusundaki hassasiyetini "kamusa uzanan el namusa uzanmıştır," (Meriç, 1985: 77) sözleriyle ifade eden Cemil Meriç, kutsal metinlerin tercümesinde de son derece duyarlıdır. Zira ona göre tercüme edilen metinler bir avuç toz olmuş kelebek gibidir. (Meriç, 2010: 79) Ezan yasağını zor kullanarak devam ettirenleri ise Meriç, Hıristiyanların anlamadıkları halde Latinceyi din dili olarak kullanmalarından delil getirerek eleștirmektedir:

"Bir devlet ki, bütün bir köyün sevgisini kazanan yaşlı din adamını Arapça ezan okuyor diye tartaklayacak kadar şuursuz ve eblehtir. Bütün Hıristiyan dünyanın, tek kelimesinin anlamadan, Latince dua ettiğini bilmez." (Meriç, 1995: 380)

Ezanı salt bir namaza çağrı aracı olarak düșünmek onun hem dil hem de dini cephesinin göz ardı edilmesi demektir. Ezan, ötelerden sunduğu manevi rahatlama ile huzur getiren bir sedadır. (Aydar, 2017: 193) Karşılandığı zannedilen kelimelerle değil, genelde insanoğlunun özelde Müslümanları ruhunda uyandırdığı duygularla onları felaha çağırır. Bu meyanda Nihat Sami Banarlı, Yahya Kemal'in şu yerinde değerlendirmesini aktarır: “Kur’an ilim kitabı değil, bir iman kitabıdır. Müslüman Türk halkı onu söz olarak değil, ses olarak okur, anlayamadığı yerlerini de sesin tesiriyle hissetmeye alıșmıștır." (Banarlı, 1986: 97-98) Aynı şekilde Yahya Kemal, tıpkı Kur'an gibi ezanın da bizimle manasıyla değil sesiyle iletişim kurduğunu şu cümlelerle dile getirmiştir: “Ezan bir ses’tir. Minarelerden yükselerek Müslümanların gönlüne dalan bir musikidir. Ayasofya'da ilk defa hangi kelimelerle okunmuşsa onu öyle muhafaza etmek lazımdır. Ezana bu sesi, bu musikiyi biz verdiğimiz için bu ses millidir." (Banarlı, 1984: 27)

Sembolik anlamıla ezan, Müslüman bir birey açısından, dini pratiği bir tarafa, onun İslam toplumuna aidiyeti ve ruhsal sağlığı açısından önemli bir toplumsal hafıza göstergesidir. Çünkü o Müslüman kimlik inşasının en temel yapı taşlarından biridir. İsmet Özel’in “Amentü” şiirinde ifade ettiği gibi, Türkçe ezan 
Müslüman hafızasında "binlerce yılın yabancısı bir ses" mesabesindedir. Özel'in, babasının polis olmasından da yola çıkarak betimlediği durum, Türkçe ezan uygulamasının en trajik resimlerinden biridir:

"Ezan sesi duyulmuyor

Haç dikilmiş minbere

Kâfir Yunan bayrak asmış

Camilere, her yere

Öyle ise gel kardeşim

Hep verelim elele

Patlatalım bombaları

Çanlar sussun her yerde

Çanlar sustu ve fakat

Binlerce yılın yabancısı bir ses

Değdi minarelere:

Tanrı uludur, Tanrı uludur,

Polistir babam

Cumhuriyetin bir kuludur." (Özel, 2005: 90-91)

Türkçede günlük dilde Allah da yaygın olarak kullanılıp anlaşılmasına rağmen, "Allah büyüktür" yerine Atatürk'ün beğenisi, tercihi ve emri ile "Tanrı uludur,” terkibinde karar kılınmıştır. (Akgün, 1980: 109-110; Çağlayan, 2008: 119) Bu 53 tercih de belki Türkçe ezanın tutmamasının en temel sebeplerinden biridir. Zira bu iki kavramın çok hassas bir dönemde karşı karşıya getirilmesi Allah’a karşılık Tanrı'nın devlet ve yönetim tarafından zorla dayatılması manasına gelmekte idi. (Aydın, 2002: 466) Daha net ifade etmek gerekirse:

"Bu süreçte Allah kavramına karşı koşulsuz alternatif olarak sunulan ve ezanın yerine ikame edilmeye çalışılan 'Tanrı uludur' nidasıyla zihinlere kazınan Tanrı kavramı Müslüman halkın nazarında Allah kavramından farklı, onunla asla aynı anlama gelmeyecek bir kavrama dönüşmüştür. Allah demenin suç sayılıp yerine Tanrı kavramının dayatılması neticesinde Tanrı kavramı hem anlamını yitirmiş hem de ezanı ve Kur'an'ı Türkçeye çeviren zihniyetin temsilcisi olarak görülmüştür." (Atay \& Çiftçi, 2013: 316)

Özetle ezanı Türkçeleştirme girişimi, ezanın Müslüman zihin dünyasındaki sembolik anlamını zedelemiştir. Dahası işin içinde zorlamanın olması, insanlardaki direnci ve reddi bir yere kadar tetiklemiş ve artırmıştır. Şimdi anadilde ibadet tartışmaları ve Türkçe ezan uygulamasının ortaya çıktığı şartlara kısaca değinebiliriz.

\section{Anadilde İbadet Tartışmaları ve Türkçe Ezan}

Ali Suavi, Hocazade Mehmet Ubeydullah (Cündioğlu, 1998: 23-24) ve Ziya Gökalp'in başını çektiği anadilde ibadet tartışmaları Tanzimat ve Meşrutiyet'e kadar 
gitmektedir. (Bozkurt, 2017: 295) Öncelikle, inkılapların çoğunda olduğu gibi bu konuda da Cumhuriyet kadrosuna ilham oluşturduğu ileri sürülen (Parla, 1993: 208; Gez, 1996: 158; Dikici, 2006: 78) Ziya Gökalp'ın 1918'de Yeni Hayat Dergisi'nde yayımladığı meşhur şiiri “Vatan”ın ilgili mısralarına göz atalım:

“Bir ülke ki, camiinde Türkçe ezan okunur,

Köylü anlar manasını namazdaki duanın...

Bir ülke ki, mektebinde Türkçe Kur'an okunur

Küçük büyük herkes bilir buyruğunu Huda'nın...

Ey Türk oğlu, işte senin orasıdır vatanın!” (Akgün, 1980: 106; Ceylan, 1996: 20)

Şiirde geçen Türkçe ezan, dua ve Türkçe Kur'an konularının íkinci Meşrutiyet'ten itibaren sıklıkla gündeme geldiği bilinmektedir. (Göküş, 2013: 218226, 230-235) Bu bağlamda Mehmed Ubeydullah Efendi'nin Türkçe namaz kıldırmak için Talat Paşa'dan izin istediği, onun ise şartların uygun olmadığı gerekçesi ile buna izin vermediği bilinmektedir. Şartları olgunlaştırma babında Kur’an tercümelerinin önce dergilerde tefrika edildiği sonrasında da ayrıca basıldığı bilinmektedir. (Cündioğlu, 1998: 20) Genelde din özelde de ibadet dilinin Türkçeleştirilmesi çalışmalarının Cumhuriyet'in ilanı ve inkılaplarla beraber Gökalp'ın “Vatan” şiirindeki hayalleri ve idealleri doğrultusunda hız kazandığını söylemek yanlış olmayacaktır. (Dikici, 2006: 77-78)

Gökalp'ın ilhamlarıyla yola çıkan Cumhuriyet eliti, Osmanlı bakiyesinden kalanlarla ulusal bir devlet kurmayı hedeflemiştir. (Aydar, 2006a: 63; Dikici, 2006: 78; Göküş, 2013: 87-97) Özellikle harf inkılabı ve hilafetin ilgasının bu yönde en temel adım olduğunu vurgulamak gerekir. Harf inkılabı ile maziye ait bağları, hilafetin ilgasıyla da diğer İslam ülkeleri ile olan dini ilişkileri koparan Türkiye Cumhuriyeti'nin kurucu kadroları, milli kimlik inşasının en önemli ayağı olan milli din inşası yolunda adımlar atmaya başlamıştır. (Bozkurt, 2017: 295-296) Bunlardan ilki Kur'an- Kerim'in tercümesi, tefsiri ve Buhari'nin tercümesidir. Materyal temininden sonraki adım, şüphesiz bunların camilerde uygulamaya konulmasıdır. Projenin bu boyutunu fark eden Mehmet Akif, meali bitirmesine rağmen anlaşmayı feshedip teşebbüsün bir parçası olmayı reddetmiştir. Akif'in ayrılmasıyla Türkçe ibadet girişimi önemli bir destekten mahrum olarak ciddi bir kan kaybına uğrasa da geri adım atılmamıştır. Zaten tefsiri yapmakta olan Elmalılı M. Hamdi Yazır'a meal işi de havale edilmiştir. Akif'inki kadar başarılı olmasa da akim kalmaması açısından önemli bir sonuç elde edilmiştir. Ancak, Elmalılı Muhammed Hamdi Yazır'ın Hak Dini Kur'an Dili adlı tefsirinde ayetlerin mealinde kullanılan Türkçe'nin tefsir kısmında kullanılan Türkçe'den farklı olmasının ve hatta müellifin dil hâkimiyetine rağmen meal kısmında kasten akıcı olmayan bir dil kullanmasının da aynı sebebe dayandığı ileri sürülmektedir. (Aydar, 2007: 76-77, 100; Öztürk, 2017) Yazır’ın eserin önsözüne eklediği “Haşa Türkçe Kur'an” cümlesi ve bunun kaldırılması için yaşanan tartışmalar da bu görüşü destekler niteliktedir. (Bien, 2011: 119-123; Bozkurt, 2017: 314-315) 
Bunlara ilaveten değinilmesi gereken en önemli gelişmelerden biri de "Dini Islah Beyannamesi"dir. Nasıl geliștiği, heyette kimlerin bulunduğu ve imzaladığı konusunda hayli kafa karışıklığı olmasına rağmen bazı bilgiler açık görünmektedir. Göztepe Camii imamı Cemaleddin Efendi'nin 19 Mart 1926 tarihinde Cuma namazının tamamını, hutbeden selama kadar, Türkçe kıldırması; anadilde ibadet konusu yeniden gündeme taşımış ve sonuçta hükümet Daru'l-Fünûn illahiyat Fakültesi hocalarından konuya dair bir rapor hazırlamalarını istemiştir (18 Haziran 1928). M. Fuad Köprülü’nün başkanlığındaki bir heyetin hazırladığı rapor basına yansıyınca (Vakit Gazetesi, 20 Haziran 1928) hararetli tartışmalara sebep olmuştur. Rapordaki çoğu tartışmalı teklif yanında (camilere sıra ve müzik aletlerinin konulması ve ayakkabı ile girilmesi gibi) ibadet dilinin Türkçeleştirilmesi öne çıkmış ve Türkçe ezan uygulamasının da gelişmesine vesile olmuştur. (Aydar, 2007: 81-85; Aydar, 2006b: 35-42; Bozkurt, 2017: 295-361)

Bu şartların doğurduğu ortamda çıkan Türkçe ezan konusundaki gelişmeleri kısaca şöyle özetlemek mümkündür. 1931 sonlarında Atatürk'ün emriyle dokuz hafız, Dolmabahçe Sarayı'nda ezanın, salanın, tekbirin ve hutbenin Türkçeye çevirisi için seferber edildi. 30 Ocak 1932'de ilk Türkçe ezan Fatih Camii'nde okundu ve 3 Şubat 1932'de bu kez Ayasofya'da Türkçe tekbir okundu. 18 Temmuz 1932'de Diyanet İşleri Reisliği müftülüklere ezanın Türkçe okunması emrini gönderdi. 4 Şubat 1933 tarihinde Başkanlık'tan gelen bildiri ise Türkçe ezan okumayanların "şiddetle cezalandırılacağını" bildirmekteydi. Bu aşamaya kadar Türkçe ezan uygulamasına dair yasal bir düzenleme yapmak yerine "telkin, emir ve tamimlerle" konunun takibi sağlandı. Arapça ezan ve kamet okuyanlar "kamu düzenini sağlamaya yönelik emirlere aykırılık" suçundan yargılanmakta ve değişik cezalar almaktaydı. Ancak, yasağa uymayanlar konusundaki yasal boşluklar nedeniyle ortaya çıkan karmaşa sonucu konunun yasa ile çözülmesi gündeme geldi. Meclis'te yaşanan gergin tartışmaların ardından 2 Haziran 1941'de çıkarılan kanun değişikliği ile Türkçe ezan uygulamasına muhalefet edenlerin durumu netleşti. Yeni kanun, "Arapça ezan ve kamet okuyanlar üç aya kadar hafif hapis, on liradan 200 liraya kadar hafif para cezasıyla cezalandırılırlar" hükmünü getirmişti ki buna görev dışında herhangi bir yerde okumak da dahildi. (Gez, 1996: 159-165; Ceylan, 1992: II, 359-369; Dikici, 2006: 129-130)

Türkçe ezan uygulaması, CHP milletvekillerinin çoğunluğunun "evet" oyları ile DP-CHP iş birliğiyle 16 Haziran 1950'de TBMM'de görüşülüp bir gün sonra da Resmî Gazete'de yayınlanarak 17 Haziran 1950'de resmen sona ermiştir. (Aydar, 2007: 102) Aslında kanunla getirilen düzenleme, "Arapça ezan ve kamet" okuyanlara verilen cezanın kaldırılmasından ibaretti. Yoksa ezanın hangi dilde okunacağı ya da okunmayacağı kanuna bağlanmış değildir, isteyen Türkçe isteyen Arapça okuyabilir. Buna rağmen yorumların hemen hepsinde "ezanın Arapçalaştırılmasından” söz edilmektedir. ${ }^{3}$ Halbuki böyle bir şey yoktur, yine de

\footnotetext{
${ }^{3}$ Başbakan Menderes'in ağzından haberi veren Sebilürreşad değişimi şöyle aktarır: "Şimdiye kadar baskı altında olan dinimizi baskıdan kurtardık. İnkılap softalarının yaygaralarına ehemmiyet vermeyerek Ezanı Muhammediyi Arapçalaştırdık.” “Müslümanız, Müslüman Kalacağız,” Sebilürreşad 4/94 (Ocak 1951): 290.
} 
halkın çoğunluğu nezdinde konu hep öyle anlaşılagelmiş ve değişiklik yurt genelinde bayram coşkusu içinde kutlanmıştır. ${ }^{4}$ Nihayet, Diyanet iş̧leri Başkanı Ahmet Hamdi Akseki'nin imzası ile daha önce gönderilenin aksine bir tamim gönderen Başkanlık, ezanın asli dili olan Arapça okunabileceğini yurt genelindeki bütün müftülüklere duyurmuştur. (Çağlayan, 2008: 129-130)

\section{Ezanı Nasıl Okuma(ma)lı?}

“Ezan ve Kur’an”, “Ezansız Semtler,” “Aziz İstanbul” gibi önemli eserlere imza atmış, harf ve dil devrimi gibi belli inkılaplara mesafeli durmuş ama yine de Cumhuriyet eliti ve yönetici kadro içinde yer almış Yahya Kemal'e göre Osmanlı'nın iki temeli vardır: "Fatih'in Ayasofya minaresinden okuttuğu ezan ki hala okunuyor! Selim'in Hırka-i Saadet önünde okuttuğu Kur'an ki hala okunuyor! Eskişehir'in, Afyon Karahisar'ın, Kars'ın genç askerleri siz bu kadar güzel iki şey için döğüştünüz." (Kemal, 1985: 120)5 Çanları susturup uğruna döğüștükleri bu iki değerin köklü bir şekilde değiştirilmesi "halkın tepkisine neden olmuş hatta bazen bu olaylar protesto ve ayaklanmalar şekline dönüşmüş, bazılarına ise bizzat Atatürk'ün kendisi el koymuştur." (Bozkurt, 2017: 315).

Türkçe ezan uygulamasına karşı en şiddetli muhalefetlerden birisi dönemin basınına yansıyan ve hala değişik açılardan tartışılan Bursa olayıdır. (Gez, 1996: 163; Dikici, 2008: 169-170) 1 Şubat 1933'te Ulu Cami'de meydana gelen olay Cuma namazı esnasında Arapça ezan ve kamet okunması ile patlak vermiş ve kısa zamanda toplumsal bir infiale dönüşmüştür. Önce Evkaf Müdürlüğü, ardından Vilayet önünde gösteri yapan halktan çoğu kişi tutuklanarak, kalabalık polis tarafından dağıtılmıştır. Gözaltına alınanlar ertesi gün serbest bırakılınca kararı veren hâkim Hasan Bey, savcı Sakıp Bey ve Bursa Müftüsü Nurettin Efendi görevden uzaklaştırıldıkları gibi serbest bırakılanlar da tekrar tutuklanmıştır. Ulu Cami hatibi de İstanbul'da yakalanarak Bursa'ya tutuklu olarak gönderilmiştir.

\footnotetext{
417 Haziran 1950'de ezanın Arapça okunmasının serbest olmasıyla ilgili basında yer alan haberler ezanın Türkçe okunmasından duyulan rahatsızlığı göstermesi bakımından manidardır. Ezan serbestisi ilk sayfadan okuyuculara duyurulurken bazı gazeteler bu haberi büyük puntolarla manşetten vermişlerdir. Son Posta "Ezanın din dili ile okunmasına başlandı" başlığıyla haber vererek, yasağın kaldırılışının vilayetlere ve vilayetlerden tüm ilgililere tebliğ edildiğini yazmıştır. Aynı gazetenin İzmit Muhabiri şu haberleri nakletmiştir: "Ezanın din dili ile okunması serbestliğini radyo ve gazeteden öğrenen İzmitliler bugün öğle (17 Haziran) namaz vaktini sabırsızlıkla beklemişlerdir. Müezzinler çift olarak ezana başladıklarında hocalar da halkla beraber duâ ederek hazırlanmış olan kurbanlar kesilmiştir. Halk ağlayarak birbirini tebrik edip kucaklaşmıştır. Ayrıca dün toplanan 1200 imzalı tebrik teli de bugün TBMM başkanlığına çekilerek lâikliğin hürriyete kavuşmasından dolayı dokuzuncu devre TBMM'ne İzmitliler minnetlerini bildirmişlerdir. Köylerde de ezan vakti halk kadınlı erkekli olarak camileri doldurmuşlar ve ezanı gözyaşları dökerek dinlemişlerdir." Son Posta, (18.06.1950). Ayrıca bkz.: Yeni Sabah (18.06.1950); Akşam (18 Haziran 1950); Yeni Sabah (18.06.1950); Mümtaz Faik Fenik, "Ezana Dair" Zafer (17.06.1950); Ercüment E. Talu, "Mübarek Ramazan", Son Posta (18.06.1950).

${ }^{5}$ Osmanlı bakiyesi ve Cumhuriyet döneminin önemli düşünürleri Gökalp ve Yahya Kemal sıkı dostlardır. Ancak, ikisinin de, ibadet dilinin Türkçeleștirilmesi ve ezan uygulamasının doğrudan ilgili olduğu geçmiș ve geleceğe bakışları hayli farklıdır. Y. Kemal, Gökalp'e ve onun kendini tenkit sadedinde söylediği şeylere cevap teşkil eden 30 Mart 1922 tarihinde yayınladığı "Ezan ve Kur’an” başlıklı yazısında, Gökalp için "istikbalin muhayyel bünyanını kuran dev gibi bir mimar" benzetmesini yaptıktan sonra, "ilk Müslümanlar gibi mütedeyyin, ilk Türkler gibi bani idi; maziye arkasını çevirmiş sabit bir bakışla yalnız istikbale bakardı,” değerlendirmesinde bulunmaktadır. Kendisinin mazi hasreti karşısında Gökalp'ın meșhur tenkidi, "Harâbîsin harâbâtî değilsin / Gözün mâzîdedir âtî değilsin” beytini zikrettikten sonra kendi cevabını da "Ne harâbî ne harâbâtîyim, / Kökü mâzîde olan âtîyim" șeklinde sunmuștur. (Kemal, 1985: 119)
} 
Mülki ve idari erkân olayın büyütülmeden kapatılmasını arzu etmişlerse de dönemin belediye başkanı Ali Muhiddin Dinçsoy'un yıldııım telgrafıyla meseleyi “Bursa'da irticai ayaklanma oldu” diye Atatürk'e ulaştırması her şeyi altüst etmiştir. İzmir'de bulunan Atatürk, hemen yola çıkıp, Afyon-Bilecik üzerinden devam ederek 5 Şubat sabahı Bursa'ya gelmiştir. Kendisine daha önce dahil olan İnönü'ye ilaveten İçişleri ve Adalet Bakanları da Bursa'ya gelip yerinde incelemelerde bulunmuşlardır. Olayın abartıldığı kadar büyük olmadığını ama ilgililerin mutlaka cezalandırılacağını ve inkılaplar konusunda geri adım atılmayacağını belirten Atatürk, ortalığı yatıştırarak Bursa'dan ayrılmıştır. (Ceylan, 1992: II, 415-421; Ceylan, 1996: 89-101; Dikici, 2006: 84-87)

Soruşturmalar sonunda Bursa olayı ile ilgili olarak aralarında müftü, caminin hatibi ve bir de fabrikatörün olduğu 24 sanık 15 Şubat 1933 tarihinde Bursa Ağır ceza mahkemesine sevk edilmiştir. Sanıkların Çorum'a nakledilmesiyle Çorum Ceza Mahkemesi'nin karara bağladığı davada 1 Mayıs'ta verilen kararla aralarında müftü ve kâtibinin de bulunduğu "dört kişi beraat ederken, beș kişi ikişer yıl ağır hapis, yedi kişi birer yıl ağır hapis, yedi kişi de beş ay ağır hapis cezasına çarptırıldı." (Ceylan, 1992: II, 415-421; Ceylan, 1996: 89-101; Dikici, 2006: 84-87)

Sebilürreşad'ın yeniden yayınlanmaya başladığı 1948'li yıllarda nispeten rahatlamaya başlayan ortama rağmen derginin satırlarına yansıyan bir cezalandırmaya burada işaret etmek yerinde olacaktır. "ibadetlere kanun müdahale edebilir mi? Demokrasiye, Laikliğe, Vicdan Hürriyetine ve Anayasaya $\underline{ }$ Aykırı Bir Kanun” başlığı ile verilen haberin devamı şöyledir:

Kütahya Sulh Ceza Mahkemesi'nin 6/4/1948 tarih ve 43 esas ve 258 numaralı kararına göre Mehmet Ali Çorum ve Osman Yaz, 19/12/1947 Cuma günü Takvacılar ve Yeşil Camilerde iç ezanı Arapça okumaktan sanık olarak yargılanmışlardır. 22/12/1947 tarihinden 26/2/1948 tarihine kadar tutuklu kalan sanıklar, yargılama sonunda Türk Ceza Kanunu'nun 526'ncı maddesinin ikinci fıkrası gereğince üçer ay hapse mahkûm edilmişlerdir. İki aydan fazla süren tutukluluk süreleri cezalarından düşülen sanıkların temyize götürdükleri kararın gerekçelerinden biri hayli ilginçtir. Mahkeme, muhtemelen kararın inandırıcılığını ispat sadedince estetik duyguya hitap etmeyi gerekli görerek sanıkların eylemini "Dini ve ilahî sıcaklığını ve heyecanını ruhların ve vicdanların duymasına imkân olmayan Arapça diliyle ezan okumaları" nitelemesiyle kayıtlara geçirmiştir. (Edip, 1948: 60) Dergi ise iktidardaki CHP ve muhalefetteki Demokrat Parti milletvekilleri ve bağımsızların demokrasi, laiklik, insan hak ve özgürlüklerine aykırı bu tür kanunları değiştirmek için hiçbir gayrette bulunmadıklarından şikâyetle haberi noktalamaktadır. Sebilürreşad Haziran 1948'deki 5 ve 6 nolu sayılarında da bu cezai kararla ilgili manşetler atarak konuyu gündeme taşımaya devam etmiştir. (Edib, 1948: 66-67; 1948: 82, 86)

Basına yansıdığı ya da yazıldığı kadarıyla, yukarıdaki gibi yüzlerce vakıayı dönemin medya sayfalarında bulmak mümkündür. (Zengin, 2014:167-180; Dikici, 2006: 88-93; Dikici, 2008: 169-170; Zengin, 2015: 19-39) Mesela, Ankara'nın Çubuk ilçesi Guruveren Köyü'nden Yusuf Özcan, Arapça ezan okuduğu için 80-100 kez 
nezarette kalmış, sekiz kez hapiste yatmış ve beş ayrı kez toplamda 17 ay akıl hastanesinde yatırılmıştır. (Ceylan, 1992: III, 372-384) Yine Çubuk Karadana Köyü’nden Sadık Çakırtepe, ilk kez 1933 Bursa Olayı'nda olmak üzere 1946, 1947 ve 1948 yıllarında yargılanmış ve “on kez hapis” ve “on kez de Bakırköy Akıl Hastanesi'ne” yatırılmıştır. (Ceylan, 1992: III, 385-392)

Aradan yarım asırdan fazla zaman geçmesine rağmen, halkın hafızasında yer alan çoğu hikâyede ezan dayatmasının ortaya çıkardığı travmaların izleri hala dünkü gibi canlıdır. (Armağan, 2018) Memleketin her köşesinde benzer hikâyelere rastlamak mümkündür; ister güney ister kuzey ister doğu ister batıya gidelim, taşra ya da merkez farkı olmaksızın bu tür hikâyelerin ülkenin her karışında mevcut olduğu görülecektir. ${ }^{6}$ Doğum yerim, i̇ç Anadolu'nun bağrında yer alan Karaman'ın Başkışla Köyü'nde Abdurrahim Yaşar amcadan dinlediğim hikâye bunlardan biridir.

Bugün yetmişli yaşların ortasında olan Abdurrahim amca henüz çocuk yaşlardadır. Camiye komşu olan evlerinin damından, yaşlı imam Mehmet Efendi'nin cami kömürlüğünün damında titrek elinde bir kağıtla zorla Türkçe ezan okuyup ağladığını görünce, gülmüş ve babasına yakalanmıştır. Babası hemen orada oğlunu terbiye sadedinde "Görmüyor musun adamın ne güçlükle okuduğunu, bir de gülüyorsun!” diyerek paylar ve iyi bir tokat atar. Bu hadise, küçük Abdurrahim'in halim selim bir insan olan babasından dayak yediği ender iki andan biridir. Abdurrahim amcanın 1942 doğumlu olduğu göz önüne alınırsa, olayın 1948-49 civarında olmuş olması mümkündür.

Bu, sıradan gibi görünen olayın neredeyse birebir aynısı aynı yıllarda güneyin incisi Antalya'nın Demre ilçesinin bir köyünde yaşanmıştır. 2012 yılında bir konuşma için gittiğim Demre'de Molla Amca diye seksen yaşlarında bir yaşlının çevresindekilerin desteği ile konuşmaya geldiğini gördüm. Program sonunda yer alan çay kahve faslında "Sizin mollalığınız nereden geliyor?" diye sordum. "Benim mollalığım falan yok. Babam köyümüzün imamı idi. Beni okutmak istedi; biraz bir şeylere başladık ama ben kaçtım. Oradan yaladığımız mürekkebin kalıntısı ile adımız mollalığa çıktı." diye cevap verdi. "Babanız hoca ise sizde Türkçe ezana dair hatıralar vardır," diyerek sohbeti sürdürdüm. Biraz hüzünlendi ve anlatmaya başladı: "Türkçe ezan uygulaması başlayınca, babam ben bunu yapamam diye istifa edip kendi işi ile meşgul olmuş. Köyde dini bilgisi en az olan biri bu işe memur edilmiş. Ama o kadar kötü ki, Cuma hutbesinde duaları yanlış okuyunca babam oturduğu yerden düzeltirmiş. En hazini ise ikindi namazından çıkan cemaatin cami avlusunda toplanıp babam dışarı çıkınca, 'Haydi, hocayı dağa götürelim, okutup okutup ağlayalım,' demeleri idi."

Güneyden kuzeye geçerek, Türkçe ezan uygulamasının Karadeniz'deki insanların vicdanında açtığı yaralara dair bir anekdota göz atmak yerinde olacaktır. İsmail Kara, fahri ve resmi imamlık yaparak emekli olan babasının hatıralarını

\footnotetext{
${ }^{6}$ Aslında çalışmaya başlarken, sosyal tarih açısından çok önemli olduğunu düşündüğüm bu tür hatıraların bir derlemesini yapmaya niyetlenmiştim. Ancak zaman darlığı farklı bir yazı ortaya çıkardı. Hepsi olmasa da ulaşabildiğim birkaç hatırayı yazıya ekleyerek asli plana kısmen sadık kalmaya çalıştım.
} 
Cumhuriyet Devrinde Bir Köy Hocası alt başlığı ile derlediği kitabında babası Kutuz Hoca'nın şöyle bir hatırasını nakleder. Türkçe ezan uygulamasının başladığı yıl henüz çocuk olan hoca Rize'dedir. Ona bu yaşta eğlenceli de gelen uygulamayı makamı ile beraber hemen ezberler. Ama işin vahametinin farkında olan şehirdeki yaşlı hocaların olaydan son derece rahatsız olarak "bir kısmının Türkçe ezan okunurken yere baktıklarına, haya ettiklerine, ağladıklarına şahit” olmuştur. Köye döndüğü zaman ise ezanların okunmadığını fark etmiştir, çünkü kimse Türkçe ezan okumayı bilmediği gibi “öğrenmek” istememektedir. Büyük Cami’nin imamı Oflu Serdar Hoca, muhtemelen kısmen daha güvenli olduğu için, "yalnız sabah ezanını Arapça olarak minareden" okumakta, diğer vakitleri ise "sükutla" savuşturmaktadır. Bu durum da halk arasında dedikodulara sebep olunca vazife Türkçe ezanı bilen genç Kutuz hocaya tevdi edilmiştir. (Kara, 2000: 92)

Kutuz hoca anlatmaya devam ederek olayın ikinci perdesindeki rolünü de izah sadedinde şunları paylaşmaktadır. Kaderin cilvesi sonucu "ezan asli haline döndüğü zaman” kendisi bu kez Büyük Cami’nin resmi imamıdır. Değişiklikten haberdar olmadığı için ezanı Türkçe okumaya başlamıştır. Aşağıdan değişiklik haberini duyan cemaat hocayı bağırarak uyarırlar. Hoca önce ne olduğunu anlamaz, anlayınca da şaka olduğunu zanneder. Gerçek olduğundan emin olunca da ezanı Arapça okumaya başlar. Minareden halkın tepkisini ve olup biteni gayet iyi gözetleyebilen hoca sözlerini şöyle noktalamaktadır: "Kadın erkek herkes camiye doğru koşarak gelmeye başladı, uzak evlerde ise insanlar avluya çıtılar. Bir bayram havası, bir basü bade'l-mevt yaşandı o gün." (Kara, 2000: 93) Ezanın asli haline dönmesi ile yaşananları ifadede dönemin ruhunu özetleyen sihirli terkibin "bayram havası" olduğunu vurgulamak gerekir.

Bu gerçek, defalarca değişik kaynaklarda zikredilmekle birlikte, dönemin İslami basınından Sebilürreşad'ın sahibi ve başmuharriri Eşref Edib en iyi vurgulayanlardan biridir:

“Bin üç yüz küsur senden beri bütün dünyadaki Müslümanlar, bunu Peygamberimiz zamanında okunduğu veçhile Kur'an diliyle okurlar. Bu İslam vahdetinin en büyük sembolüdür. Her millet, bunu kendi lisanına tercüme etmeğe kalkışırsa bu vahdet parçalanır. Her Müslüman 'La ilahe illallah Muhammedün Resulullah' derken bütün ruhiyle iman zevkini duyar. Bunun yerine 'Tanrıdan başka yoktur tapacak. Tanrının elçisidir Muhammed' demekle hangi Müslüman var ki o zevki duyabilsin? Bu, Müslümanların iman ve itikatlarıyla alay etmekten başka bir şey değildir." (Edip, 1950: 78)

Ali Ulvi Kurucu'nun hatıratında naklettiği Zekai Efendi Hoca da Türkçe ezan uygulamasının ilginç mağdurlarından biridir. 1930'lu yıllarda Konya'da Aziziye Camii'nde güzel sesi ile müezzinlik yapan mevlithan Zekai Efendi, ezanın Türkçe okutulacağını duyunca hepsi aynı zamanda hocaları olan Ali Ulvi'nin dedesi, babası ve amcasına şöyle dert yanmıştır: 
"Efendim belki işitmişsinizdir; benim kulağıma geldi. Yakınlarda ezan değişecekmiş... Bendeniz ezanı, bir İlahi emir olarak telakki ediyorum... Peygamber-i Zişan, bu emri takrir buyurdular, kabul ettiler, bunu tatbik edelim, dediler... Binaenaleyh bu muhalefete benim gönlüm razı olmuyor... Terk-i diyar eyleyeceğim, muhacir olacağım. İnşallah ezan aslına dönünceye kadar dönmeyeceğim. Uydurma ezanı okumamaya niyet ettim. Allah'tan bunu diledim... Efendim vedaya geldim.” (Düzdağ, 2018: 25-28)

Kendisine nereye gideceği sorulan Zekai Hoca, “Kıbrıs'a” gideceğini söyleyerek yola koyulur. Kıbrıs'taki ilk ezanını Magosa Camii'nde okur ve ezan okurken caminin önüne doluşan kalabalığı görerek memnun olur ve Kıbrıslıların din diyanetle alakasının az olduğuna dair ön yargının ne kadar yanlış olduğunu düşünür. Sevinçle aşağı indiğinde birkaç ihtiyar ve görevliler dışında boş gördüğü caminin halini namazdan sonra ilgililer açıklar. Namazlar ve camiler hep böyle tenhadır, ancak ezan esnasında dışarıda biriken halk onun sesini ve ezanını beğenmiş ve onu dinlemeye gelmiştir. Türkçe ezan açısından hayli ilginç olan bu tecrübeye Zekai Hoca üç sene zor dayanmıştır. Ezan aslına dönmediği için Türkiye'ye dönemediğinden takriben 1935 yılında Medine'ye hicrete karar verir. Kıtlık ve yokluk içinde kendisine onca yıl katlanan eşi ise memleketi Konya'ya dönmeye karar verir. Zekai Hoca önce Mekke'ye gidip bir süre kaldıktan sonra Medine'ye vasıl olur. Her defasında eşini yanına davet ettiğinde o da onu Konya'ya geri çağırır. Aradan neredeyse yirmi yıl geçer ve birleşemezler. (Düzdağ, 2018: 2829) Nihayet 1950'de ezan aslına dönünce hoca da 1954'te sıla-i rahim için memlekete gelir. Konya'dan komşusu ve ahbabı olan dönemin Diyanet isşleri Başkanı Eyüp Sabri Hayırlığlu'nu da bilvesile Ankara'da ziyaret eder. Hayırlığlu, mesleğinde gayet yetkin ve hizmet yaşının olgunluk yıllarındaki bu değerli dostunu yeniden memlekete kazandırmak için, ona önceki imamın vefatı ile halen münhal olan Hacı Bayram Camii imamlığını teklif eder. Hocanın gönlü bu teklife akmakla beraber, öte tarafta da Medine-i Münevvere olunca karar veremez. Medine'ye dönünce, Kadiri Şeyhi Ziyaeddin Efendi'ye görüş sormak üzere ziyarette bulunur; şeyh efendi kısa bir mülahazadan sonra, gitmesini tavsiye eder. Zekai Hoca da tavsiyeye uyarak yaklaşık yirmi yıl aradan sonra Hacı Bayram Camii'ne imam olarak döner. (Düzdağ, 2018: 37)

Son olarak, Türkçe ezan uygulamasının aydınlar üzerindeki izlerini gösteren bir başka anekdota yer vermek istiyorum. Sebilürreşad'ın sayfalarına yansıyan, M. Raif Ogan'la Atatürk'ün konu ile ilgili olarak görevlendirdiği ve çeşitli aşamalarda uygulamaya dahil olan Hafız Ali Rıza Sağman arasında cereyan eden tartışma dönemin aydınlarının durumunu resmetmesi açısından oldukça manidardır. Derginin, Aralık 1950 tarihli 92 nolu sayısında Ogan, "Hasan Ali Yücel avukatının tuhaf davası” başlıklı bir yazı yayınlar. Yazıda, “Tekbir’ Türkçeye döndürüldü ve 'Ali Rıza Sağman' nam kişinin 'Millet' mecmuasında açıkladığına göre yanındaki hanendelerle Dolmabahçe'deki rakı sofrasında tekrarlanmak suretiyle tecrübeleri 
yapılarak beğendirildi ve öylece tatbikine de geçildi.” (Ogan, 1950: 261) şeklindeki iddiayı gündeme getirir.

Sağman, kendini savunma adına, Şubat 1951 tarihli 95 nolu sayıya bir cevap gönderir. Dergi yönetiminin "O müthiş sele karşı duramadık. Bir Saman Çöpü gibi bizi sürükledi. Fakat davayı yine biz kazandık. Türkçe Kur’an olmaz ve okunmaz.” başlığıyla yayınladığı cevapta Sağman'ın sözlerinin devamı dönemin aydınlarının yaşadığı travmayı açıkça resmetmektedir. İnsan, geriye dönük bir okuma yaparak ön yargılı kararlarına çabucak malzeme bulabilir. Ancak, gerçek her zaman görünenden ve ilk akla gelenden daha karmaşık ve kavraması daha güçtür. Bu açıdan onu ortaya çıkarmak için daha çok çabalamak ve ön yargıları bir tarafa bırakmak gerekir. Bu meyanda Sağman’a kulak verirsek, onun ve dönemin diğer din adamlarının insan olarak yaşadıklarından etkilenmemek elde değil:

"Rakı masalarında oturmam. Eğer hasbelicab oturduğum vaki ise, bu, kerhendir... Burada hülasa olarak derim ki: Azim ve pür dehşet bir sel önünde bir koca kütük olamadık. Herkes gibi biz de resmî ve sivil köpükler ile gelen bu sel önünde bir saman çöpü durumuna düşmüştük. Falan kişinin bu selden ürkmediğini, kimse iddia edemez. Böyle bir iddianın ne kadar yalan olduğunu, arzu edenlere açıklayabiliriz... Tanzimat ile başlayıp aydın gençlerin kafalarına tutunan ve 20'nci asrın başlarında Ziya Gökalp ile temevvüç eden fikir bizim 1931'deki o hareketimiz ile fiilen öldürülmüştür. Bu suretle iyice anlaşılmış olduk ki; Türkçe Kur’an olamadığı gibi, Türkçe Kur'an okunamaz da." (Sağman, 1951: 312-313)

Hem haberin başlığında hem de Sağman'ın cevabında kullanılan “Türkçe Kur'an” ifadeleri bizi yanıltmamalı. Zira Sağman'ın suçlanması öncelikle ezan ve tekbirin Türkçeye çevrilip okunmasından kaynaklıdır. Ayrıca, dönemin tartışmaları çerçevesinde anadilde ibadet, hutbe ve namazlardaki kıraat ve dualarla ezan, sala ve tekbirin de Türkçe yapılmasını içermektedir. Sağman, "Türkçe Kur’an olamaz," sözleri ile bütün bu girişimlerin başarısızlığına işaret etmiştir.

\section{Sonuç}

1932 Ramazan ayında başlayıp on sekiz yıl sonra yine Ramazan ayında 1950 yılında kaldırılan ve sonraki hemen her darbede gündeme getirilen (Dikici, 2006: 97) Türkçe ezan ve anadilde ibadet konusu, Cumhuriyetle beraber ortaya çıkmış değildir. Aksine milli din ve anadilde ibadet tartışmaları aslında Tanzimat ve Meşrutiyet'e kadar uzanmaktadır. Milli kimlik ve milli din konusunda ısrarlı olan Cumhuriyet eliti, bu tartışmaların oluşturduğu zeminden güç alarak Türkçe ezan denemesine kalkışmıştır. 1932'de tamimlerle başlayan uygulama, 1942'de kanuna uymayanlara para ve hapis cezasının getirilmesiyle Türk toplumunun ruhunda ciddi travmalara yol açmıștır. On sekiz yıl gibi uzun bir süre devam etmesine rağmen geri adım atılmak zorunda kalınan bu teşebbüs acaba neden başarılı olamamıştır? 
Birincisi ve en önemlisi, ezanın dinin en bariz, en belirgin ve en yaygın aracı olmasıdır. Bu kadar belirgin ve köklü bir göstergeyi değiştirmeye kalkmak çok tehlikeli ve riskli bir adımdı ve sonuç olarak tutmadı. Dinin diğer göstergelerinde milli yönler ve esintiler doğaldır ve vakidir ama ezan gibi bir şeyi değiştirmek neredeyse imkansızdır. Bernard Lewis'in ifadesiyle, “Osmanlı Devleti'ni cumhurbaşkanı, bakanlar ve parlamentodan oluşan bir ulus devlete dönüştürmek mümkündü. [Fakat] camiyi sıralar, org ve koro şefi imamdan oluşan Müslüman kilisesine dönüştürmek imkansızdı." (Lewis, 1968: 415) Özellikle Protestanlık ve yeni dini hareketler dikkate alındığında Hıristiyan mezhepler arasında ciddi yorum farkları vardır ancak hepsi çanı kiliseye davet için kullanmaktadır. Aynı meyanda İslam ülkelerinin tamamında ezan evrensel bir çağrı aracı olarak kullanagelmiştir ve muhtemelen kıyamete kadar da değişmeyecektir. Çünkü mesele anlam meselesi değil gösterge meselesidir, diğer bir ifadeyle araç amaçtır.

İkincisi ve daha trajik olanı ise kanunun uygulanmasının daha sonra hapis cezasına bağlanmasıdır. Ezan gibi yaygın ve köklü bir geleneği değiştirmede hem direnç hem de muhalefet beklenen bir şeydi. Şiddetli dirençle karşılaşan dönemin tek parti iktidarı, geri adım atmak yerine son bir gayretle daha riskli bir yol tutmayı tercih ederek cezai müeyyideleri getirmiştir. Ancak bu metot, meselenin çözümünden ziyade kangren olmasına neden olarak uzun vadede iktidar kaybına yol açıp yeni bir hükümetin doğmasına ve ezanın aslına döndürülmesine sebep olmuştur.

Sonuncusu ise konunun siyasi ve politik boyutudur. (Cündioğlu, 1998: 15-16) Dinle arasına ciddi bir mesafe koyan genç Cumhuriyet, Tevhid-i Tedrisat Kanunu ile din eğitim ve öğretiminin önünü neredeyse tamamen kapatmıştır. Bunun doğal sonucu olarak da çoğu cami kapanmış, el değiştirerek uygun olmayan şekillerde kullanılmış hatta kapısına kilit vurulmuştur. Dini hassasiyetin bu kadar yüksek olduğu bir dönemde açık kalan camilerde de Türkçe ezana devlet zoru ile geçiş denemesi elbette muhalefetle karşılaşmıştır. Bu ortamda konunun siyasete taşınması kaçınılmazdı. Çünkü şöyle ya da böyle çok partili ortamlarda hemen her konunun bir oy karşılığı vardır. Demokrat Parti'nin siyasi yarışa resmen girdiği seçimlerde seçmene vadettiği konulardan birisi de ezanın asli diline döndürülmesi idi. Nihayetinde seçmen, küçük bir ışık da olsa Demokrat Parti'nin bu ve diğer dini konularda kendisini rahatlatacağını ümit ederek oy vermiş ve karşıı̆̆ını almıştır. Böylelikle, siyasi iradenin tercihi ile on sekiz yıl denenip Türk toplumunda ciddi travmalara yol açan Türkçe ezan uygulaması yine siyasi irade ile sonlandırılmıştır.

\section{Kaynakça}

Akgün, S. (1980). “Türkçe Ezan”. Tarih Araştırmaları Dergisi 13 (24), 105-113. Armağan, M. (2018). Türkçe Ezan ve Menderes. İstanbul: Ketebe Yayınları. Atay, R., Çiftçi, E. (2013). "Din Dili Çerçevesinde Süleyman Çelebi'nin Mevlid'inde Tanrı Kavramının Serüveni". Marmara Üniversitesi IIlahiyat Üniversitesi Dergisi 44(1), 316. 
Aydar, H. (2006a). "Türklerde Anadilde ibadet Meselesi- Başlangıçtan Cumhuriyet Dönemine Kadar". İstanbul Üniversitesi Illahiyat Fakültesi Dergisi 14, 47-65.

Aydar, H. (2006b). "Dârülfünûn Illahiyat Fakültesi ve Türk Kültür Hayatına Katkıları". İstanbul Üniversitesi Illahiyat Fakültesi Dergisi 13, 23-43.

Aydar, H. (2007). "Türklerde Anadilde ibadet Meselesi- Cumhuriyet Dönemi". İstanbul Üniversitesi İlahiyat Fakültesi Dergisi 15, 71-107.

Aydar, H. (2017). "Tarih Boyu Ezana Yapılan İlaveler". Şırnak Üniversitesi Ilahiyat Fakültesi Dergisi 8 (18), 193.

Aydın, H. (2002). "İslâm'da íbadetin Kur'ân Nazmı ile Kayıtlılığı Meselesi". İslâmi Araștırmalar Dergisi 15(4), 466.

Banarlı, N. S. (1984). Nihat Sami Banarlı'nın Kaleminden Yahya Kemal Bir Dağdan Bir Dağa. İstanbul: Kubbealtı Neşriyat Yayınları.

Banarlı, N. S. (1986). İman ve Yaşama Üslubu. İstanbul: Kubbealtı Neşriyat Yayınları.

Bien, A. (2011). Ottoman Ulema, Turkish Republic Agensts of Change and Guardians of Tradition. Stanford, California: Stanford UP.

Bozkurt, B. (2017). Mehmet Şerafettin Yaltkaya Hayatı, Eserleri ve Düşünce Dünyası. İstanbul: Divan Kitap.

Ceylan, H. H. (1992). Cumhuriyet Dönemi Din Devlet Iliş̧kileri II-III. Ankara: Rehber Yayıncılık.

Ceylan, H. H. (1996). Kemalizmin Türkçe Ezan Hikayesi. Ankara: Rehber Yayınları.

Cündioğlu, D. (2005). Meşrutiyet'ten Cumhuriyet'e Din ve Siyaset. İstanbul: Kaknüs Yayınları.

Cündioğlu, D. (1998). Türkçe Kur'an ve Cumhuriyet ideolojisi. İstanbul: Kitabevi Yayınları

Çağlayan, A. (2008). Asr-ı Saadetten Günümüze Ezan. İstanbul: Kayıhan Yayınları.

Düzdağ, M. (2018). Üstad Ali Ulvi Kurucu Hatıraları. İstanbul: MED Yayınevi.

Dikici, A. (2006). "ibadet Dilinin Türkçeleştirilmesi Bağlamında Türkçe Ezan Denemesi ve Buna Gösterilen Tepkiler". Yakın Dönem Türkiye Araștırmaları 5(10), 90-91.

Dikici, A. (2008). " Millî Şef İsmet İnönü Dönemi Laiklik Uygulamaları". Ankara Üniversitesi Türk Inkılâp Tarihi Enstitüsü Atatürk Yolu Dergisi 42, 161-192.

Doğrul, Ö. R. (1955). Tanrı Buyruğu. İstanbul: Ahmet Halit Kitapevi.

Edip, E. (1948, Haziran). "Hükümetin Programı ve Ezan Meselesi". Sebilürreșad 1(4), 60.

Edip, E. (1948, Haziran). "Dâvamız İslâmın izzet ve şerefi dâvasıdır". Sebilürreşad $1(5), 66-67$.

Edip, E. (1948, Haziran). "Cumhur Başkanından bir istirhamımız var". Sebilürreşad $1(6), 82,86$.

Edip, E. (1950, Haziran). "Hükümetin Programları ve Ezan Meselesi". Sebilürreşad 3(80), 78.

Fenik, M. F. (1950, Haziran 17). "Ezana Dair". Zafer Gazetesi.

Gez, B. O. (1996). "ibadet Dilinin Türkçeleştirilmesi Aşamalarından Biri: Türkçe Ezan ve Uygulamaları." Çağdaş Türkiye Tarihi Araştırmaları Dergisi 2 (6), 157-167. 
Göküş, Ş. (2013). II. Meşrutiyet Dönemi Türkçülük Akımında Eğitim, Din Eğitim ve Öğretimi (Basılmamış Doktora Tezi). Ankara Üniversitesi Sosyal Bilimler Enstitüsü, Ankara.

Gürsu, O. (1999). Günümüzde Tasavvuf Yoluyla İslam'a Yönelişin SosyoPsikolojik Analizi (Basılmamış Y. Lisans Tezi). Uludağ Üniversitesi Sosyal Bilimler Enstitüsü, Bursa.

İnce, N. N. (2010). "Geçmişten Günümüze Zâd Sesi Tartışmaları". Selçuk Üniversitesi Ilahiyat Fakültesi Dergisi 30(2), 165-180.

İnce, N. N. (2015, Aralık 15). "İzlak Bir Artikülasyon Konusu Mudur?". Cumhuriyet Üniversitesi İlahiyat Fakültesi Dergisi 19(2), 71-205.

İnce, N. N. (2016, Haziran). "Arap Dili Fonetiğinde Bazı Kavramların Yansıttığı 'Ses Üretiminde Süre' Olgusu Üzerine Bir Deneme". Cumhuriyet Üniversitesi Ilahiyat Dergisi 20(1), 117-146.

Kısakürek, N. F. (2003). Çile. İstanbul: Doğu Yayınları.

Kamiloğlu, R. (2010). "Türk Kültüründe Ezan ve Makamları". Hikmet Yurdu 3(5), 221237.

Kara, İ. (2000). Kutuz Hoca'nın Hatıraları. İstanbul: Dergah Yayınları.

Kemal, Y. (1985). Aziz İstanbul. İstanbul: İstanbul Fetih Cemiyeti Yayınları.

Koç, T. (2008). İslam Estetiği. İstanbul: İsam Yayınları.

Leaman, O. (2012). İslam Estetiğine Giriş. (N. Yılmaz, Çev.) İstanbul: Küre Yayınları.

Lewis, B. (1968). The Emergence of Modern Turkey Third Edition. London: OUP.

McLuhan, M., \& Fiore, Q. (1967). The Medium is the Message. New York: Random House.

Meriç, C. (1995). Jurnal. İstanbul: İletişim Yayınları.

Meriç, C. (2010). Sosyoloji Notları ve Konferanslar. İstanbul: Illetişim Yayınları.

Ogan, M. (1950, Aralık). "Hasan Ali Yücel Avukatının Tuhaf Davası". Sebilürreşad, 261.

Özel, ì. (2005). Erbain. İstanbul: Şule Yayınları.

Öztürk. M. (2017). “Kelime Bağlamında Elmalılı Mealinin Bazı Özellikleri”. Büyük Kur'an Mütefekkiri Elmalılı Hamdi Yazır. Ankara: Diyanet İşleri Başkanlığı Yayınları.

Parla, T. (1993). Ziya Gökalp, Kemalizm ve Türkiye'de Korporatizm. İstanbul: İletişim Yayınları.

Putnam, H. (1997). Mind, Language and Reality. Cambridge: Cambridge U.P.

Sağman, H. A. (1951, Aralık). "O Müthiş Sele Karşı Duramadık". Sebilürreşad, 312-313.

Shayegan, D. (1991). Yaralı Bilinç Geleneksel Toplumlarda Kültürel Şizofreni. (H. Bayrı, Çev.) İstanbul: Metis Yayınları.

Talu, E. E. (1950, Haziran 18). "Mübarek Ramazan". Son posta.

Wittgenstein, L. (2007). Felsefi Soruşturmalar. (H. Barışcan, Çev.) İstanbul: Metis Yayınları.

Wittgenstein, L. (1974). Tractatus Logico-Philosophicus. (D. F. Pears and B. F. McGuinness, trans.) London and New York: Routledge. 
Zengin, M. (2015). ibadet Dilini Türkçeleştirme Çabası Olarak Türkçe Ezan Örneği (Basılmamış Yüksek Lisans Tezi). Adıyaman Üniversitesi Sosyal Bilimler Enstitüsü, Adıyaman.

Zengin, S. (2014). "Zile'de Türkçe Ezana Tepki Olayı". Gaziosmanpaşa Sosyal Bilimler Araştırmaları Dergisi 9(1), 167-180. 